\title{
The recurrence risks for mild idiopathic mental retardation
}

\author{
SARAH BUNDEY, ANN THAKE, AND JUNE TODD \\ From the Department of Clinical Genetics, University of Birmingham, Birmingham Maternity Hospital, \\ Birmingham B15 2 TG.
}

SUMmARY A genetic study of children attending ESN(M) schools in Coventry has shown a recurrence risk of idiopathic mental retardation in sibs lying between 1 in 4 and 1 in 5 . There was also a prevalence of mental retardation in other relatives that was greater than the population prevalence, and was less for second degree relatives than for first degree, and less still for third degree relatives. Recurrence in sibs was greater if more than one first degree relative was affected. There was no suggestion of a contribution by $\mathrm{X}$ linked genes, once the fragile $\mathrm{X}$ syndrome had been excluded. The presence of perinatal and other environmental factors in the index children did not alter the recurrence risk for sibs except for very low birth weight. There was a low recurrence rate of mental retardation in Asian families, suggesting that they had a different distribution of intelligence from non-Asian families.

Mild, or high grade, mental subnormality is defined by an intelligent quotient (IQ) level between 50 and 70. This type of mental subnormality may have a major pathological cause, but when such a cause is lacking the retardation is considered to represent one extreme of a Gaussian distribution, which is formed by the intelligence levels of normal children. ${ }^{1}$ This continuous normal distribution of intelligence has been shown by many workers to be strongly familial, with correlations between pairs of relatives and between monozygotic twins reared together and apart, which suggests polygenic inheritance. $^{2-4}$

While the recurrence risk for sibs of index patients with severe idiopathic mental retardation is small, the recurrence of mild mental retardation in families is much higher, ${ }^{5}$ with figures ranging from 13 to $23 \% .^{6-8}$ The risks vary according to the degree of mental retardation in the index patient, and according to whether affected sibs were identified by their type of schooling or by their IQ level. An opportunity was taken to collect modern figures on the recurrence of idiopathic mild mental retardation associated with special education, when schools for children with moderate learning difficulties were investigated in order to identify children with the fragile $\mathrm{X}$ syndrome. ${ }^{9}$ In this way recurrence risks could be obtained for those children who did not have the fragile $\mathrm{X}$ syndrome.

Received for publication 26 April 1988.

Revised version accepted for publication 17 October 1988.

\section{Terminology}

Schools for children with moderate learning difficulties (MLD schools) are similar to those which used to be called ESN(M) schools. They provide education for children with educational retardation; such children often also have intellectual retardation, with IQ levels usually between 50 and 70 . However, in 1970 only about one third to one half of children with this degree of intellectual retardation actually required special education ${ }^{8}$ and probably the proportion is similar today. Index patients in this study and their similarly educationally retarded peers will be attending MLD schools, whereas members of their parents' generation will have attended ESN(M) schools, often the identical school buildings. For simplicity's sake, and in order to conform with terminology used in the earlier paper, ${ }^{9}$ we are here calling all such schools $\operatorname{ESN}(M)$ schools

\section{Methods}

There are four ESN(M) schools serving Coventry, three day and one residential. In addition, some mentally retarded children attend two schools for the physically handicapped. The records of those children attending all six schools were scrutinised, and those children with a recognisable cause for their mental retardation, such as Down's syndrome or cerebral palsy, and those children with a home address outside Coventry, were excluded. The 
parents of the remaining children were written to for permission to examine their child and take blood for chromosome studies. Those children whose parents agreed were then examined for neurological signs and body measurements, as described by Thake et al. ${ }^{9}$ Their range of IQ was determined by the shortened version of the British Picture Vocabulary Scale. A birth history was obtained from medical records and parents and birth weights were related to gestation, sex, and race, according to the centile data of Thomson et $a l^{10}$ and Brooke et al. ${ }^{11}$

Sibs were classified as mentally retarded if they had attended, or were attending, an ESN school. The same criterion was used for parents and other relatives of British and Irish children. However, since facilities for special education are absent, or differently used, in less well developed countries, we thought it best to exclude the 48 immigrant families when considering the diagnosis of mental retardation in their parents or more distant relatives.

\section{Results}

There were 439 children from Coventry attending the ESN(M) schools, 274 boys and 165 girls. They accounted for about eight per 1000 of all school children in Coventry. Eighty-eight children (20\%) were found to have a cause for their mental retardation and these are listed in table 1 . Twentyfive children had Down's syndrome and a nearly equal number ( 10 boys and 10 girls) had the fragile $\mathrm{X}$ syndrome. Of the 351 children with no apparent cause for their retardation, the parents of 116 refused participation in the study, and the parents of seven children were not available to provide family histories. Therefore, genetic information was collected on 228 children, all of whom attended an ESN(M) school between 1 January 1984 and 31 March 1985.

DEMOGRAPHIC DATA

The index children consisted of 138 boys and 90 girls and were aged between five and 16 years, with years

TABLE 1 Diagnoses found among 439 children at $\operatorname{ESN}(M)$ schools.

\begin{tabular}{lc}
\hline Diagnosis & No \\
\hline Down's syndrome & 25 \\
Fragile X syndrome & 20 \\
Other chromosome abnormalities & $2^{*}$ \\
Cerebral palsy, neonatal illness, and & $12 \dagger$ \\
intrauterine infection & $14 \dagger$ \\
Postnatal trauma or illness & 15 \\
Malformation or genetic syndromes & 88 \\
Total & \\
\hline
\end{tabular}

*47,XYY; 46,XY,t(1;14)(p23;q32).

†Accompanied by neurological signs. of birth ranging from 1966 to 1978. Information was obtained from two of the ESN(M) schools concerning age at which an index child entered school. Twenty-four percent joined the schools between four and five years, while the remaining $76 \%$ initially attended a normal school. A further $26 \%$ were transferred to an ESN(M) school by the age of eight years, and by 10 years $87 \%$ were in ESN(M) schools, leaving only $13 \%$ who were transferred later.

Among the index children, $180(79 \%)$ were English or Irish, three were Italian, one was from Chile, seven (3\%) were West Indian, 26 were Indian, two were Bengali, and nine were Pakistani (16\% total Asian). The proportions found in all Coventry school children in $1982^{12}$ were $83 \%$ British/Irish, 2.5\% West Indian, 13\% Asian, and $1.5 \%$ other races.

Social class was assessed for children at two of the schools studied, judged by the job of the father. A distribution is presented in table 2 and compared to control figures from the Coventry census. Family size is also given in this table, and because the families of the index children were mostly complete, the figures have been compared to those of mothers from Coventry who completed their families in 1984, the main year of the study. The mean parental ages at years of birth of the index children are also given in table 2 and compared to population figures.

As families from the Indian subcontinent might have different characteristics from those of English families, and the causes of mild mental subnormality

TABLE 2 Demographic data of index patients.

\begin{tabular}{lcc}
\hline & $\begin{array}{l}\text { Families in } \\
\text { study }\end{array}$ & $\begin{array}{l}\text { Control } \\
\text { population }\end{array}$ \\
\hline No of sibs of IP & & \\
0 & $9 \%$ & $17 \%$ \\
1 & $25 \%$ & $29 \%$ \\
2 & $27 \%$ & $27 \%$ \\
3 & $18 \%$ & $14 \%$ \\
4 or more & $20 \%$ & $13 \%$ \\
Parental ages & & \\
Mean maternal age & $25 \cdot 6$ y & $26 \cdot 2 \mathrm{y \dagger}$ \\
Mean paternal age & $29 \cdot 9$ y & $29 \cdot 0 \mathrm{y}$ \\
Social class & & \\
I & 0 & $4 \% \ddagger$ \\
II & $1 \%$ & $13 \%$ \\
IIIN & $11 \%$ & $8 \%$ \\
IIIM & $19 \%$ & $29 \%$ \\
IV & $36 \%$ & $18 \%$ \\
V & $10 \%$ & $5 \%$ \\
Unemployed & $22 \%$ & $21 \%$ \\
\hline
\end{tabular}

*These figures are those of earlier born sibs to mothers having babies in 1984, aged 35 and over (table $4 \cdot 1$ ). ${ }^{13}$

†Registrar General's Figures, 1972. ${ }^{14}$ Mean maternal age is for mothers in West Midlands (table GG); mean paternal age is for fathers in England and Wales (table AAb)

$\ddagger$ Figures from the 1981 Census for the City of Coventry. ${ }^{15}$ 
might be different, we considered some demographic features separately. The 37 Asian index patients consisted of 17 males and 20 females. The sibship size for the female index patients was $4 \cdot 0$, whereas for the male index patients it was $2 \cdot 3$; these figures exclude the index patient. Mean parental ages were the same as for the non-Asian families and the same as for controls. No Asian family was allocated to social classes I, II, or IIIN.

\section{CLINICAL FEATURES OF INDEX PATIENTS}

The IQ ranges of 218 of the 228 index children were measured by the British Picture Vocabulary Scale and the results were endorsed by the head teachers. They showed that 40 children (18 males and 22 females) had IQs less than 50, 117 children (67 males and 50 females) had IQs between 50 and 70 , and 61 children (43 males and 18 females) had IQs over 70 .

Nine index children had a gestation of 34 weeks or less, and seven of these had birth weights above the 10 th centile for gestation. Twenty-six children with a gestation of 35 weeks or more were admitted to a neonatal unit after birth. Forty-seven index children $(18 \%)$ had birth weights lower than the 10th centile for their gestation, sex, and race and 25 of these (8.6\% of the total) had birth weights below the 5 th centile.

Fifteen children had persistent epilepsy. No child had evidence of $\beta$ thalassaemia.

\section{FAMILY DATA}

Of the 228 index patients, six were twins and in one instance the co-twin was also an index patient. Two out of 186 English index patients had consanguineous parents and so did four out of nine Pakistani index patients. There was a total of 533 full sibs, of whom 287 were born before the index patient and 246 were born afterwards.

Considering first the sibs of index patients, 100 out of 533 full sibs $(18 \cdot 8 \%)$ were mentally retarded and so were 10 of 128 half sibs $(7 \cdot 8 \%)$. Of the full sibs, four were severely retarded (they attended ESN(S) schools) while 96 were mildly retarded. For the remainder of the analysis all 100 have been put together. Of the sibs born before the index patient, 66 out of 287 were mentally retarded $(22.9 \%)$ compared to 34 out of $246(13 \cdot 8 \%)$ of sibs born after the index patient. Of the younger sibs of index patients, $17 \%$ were aged under five years, $49 \%$ were aged between five and 10 years, and $34 \%$ were over 10 years. This age distribution raises the possibility that some sibs are not yet recognised as requiring special education. We have therefore recalculated the overall recurrence risks according to the age of sibs and these are shown in table 3 . If only sibs aged
TABLE 3 Recurrence risks in sibs of index patients according to family structure.

\begin{tabular}{ll}
\hline Category of index patient & $\begin{array}{l}\text { No (\%) of sibs } \\
\text { requiring education } \\
\text { at ESN }(M) \text { schools }\end{array}$ \\
\hline All index patients, all sibs & $100 / 533(18 \cdot 8)$ \\
All index patients, only sibs aged 8 and over & $97 / 446(21 \cdot 7)$ \\
All index patients, only sibs aged 10 and over & $91 / 379(24 \cdot 0)$ \\
187 index patients with no older affected sibs & $20 / 205(9 \cdot 8)^{*}$ \\
41 index patients with one or more older & $15 / 39(38.5)^{*}$ \\
affected sib & $66 / 442(14.9)$ \\
191 index patients with no affected parent & \\
37 index patients with one or both parents & $34 / 91(37.4)$ \\
affected &
\end{tabular}

*Subsequent born sibs only counted.

10 years and more are counted, the recurrence risk is $24 \%$.

Since the ages of the index children ranged from five to 16 years, there were several families with more than one index child. There were two trios of index patients in the same sibship and 15 pairs of index patients who were sibs, resulting in 17 families who were counted two or three times when calculating the above recurrence risks. In case this could have caused a bias, we considered the recurrence risks counting the 17 families once only. The recurrence of mild mental retardation in sibs became 78 out of $486(16 \%)$. The recurrence risk in the sibs of Asian index patients was only one out of 118 , so that the recurrence in the remaining non-Asian families was 98 out of $415(23 \cdot 6 \%)$. If sibs aged 10 and over only are included, then the recurrence in sibs of Asian index patients becomes 0 out of 73 .

In table 4 data are presented separately for male and female index patients. The female index patients belonged to larger sibships than the males: they had an average of 2.7 sibs, whereas the male index patients had an average of 2.0 sibs. For both male and female probands there was a greater risk for brothers to attend $\operatorname{ESN}(\mathrm{M})$ schools than for sisters; there were slightly higher recurrence risks for the relatives of female probands compared with those of male probands. In considering the sibships with several affected, we found that male index patients with affected sibs belonged to 16 sibships with males only affected and 16 sibships with both males and females affected. Female index patients 0 with affected sibs came from 22 sibships with both males and females affected and five sibships where only females were affected.

There were 41 index patients who had at least one older affected sib at the time of ascertainment. Among the younger born sibs in these families, the recurrence of mental retardation was 15 out of 39 $(38.5 \%)$. For those 18 index patients who had two or 
TABLE 4 Recurrence of mental retardation by sex of index patient.

\begin{tabular}{|c|c|c|c|c|c|c|}
\hline & Brothers & Sisters & Total sibs & Mothers* & Fathers* & All parents* \\
\hline 138 males & $26 / 130(20 \%)$ & $25 / 156(16 \%)$ & $51 / 286(17 \cdot 8 \%)$ & $15 / 113(13 \%)$ & $10 / 113(9 \%)$ & $25 / 226(11 \%)$ \\
\hline 90 females & $31 / 123(25 \%)$ & $18 / 124(14 \cdot 5 \%)$ & $49 / 247(19.8 \%)$ & $14 / 67(21 \%)$ & $9 / 67(13 \%)$ & $23 / 134(17 \%)$ \\
\hline All index patients & $56 / 253(22 \%)$ & $43 / 280(15.4 \%)$ & $100 / 533(18 \cdot 8 \%)$ & $29 / 180(16 \%)$ & $19 / 180(10 \%)$ & $48 / 360(13 \%)$ \\
\hline
\end{tabular}

*English and Irish families only.

more older affected sibs, the recurrence in younger sibs was six out of $18(33 \%)$. In contrast, the recurrence in younger sibs of those index patients who did not have an older affected sib was only 20 out of $205(10 \%)$.

There were 37 index patients who had one or both parents who were mildly mentally retarded. The recurrence of mental retardation in the sibs in these families was 34 out of $91(37 \%)$. In the nine families where both parents were retarded, the recurrence in the sibs of the index patient was also $37 \%$, seven out of 19 sibs affected. In contrast, for the 191 index patients with no affected parent, the recurrence in sibs was 66 out of $442(14.9 \%)$. These risks are set out in table 3.

Regarding the occurrence of mental retardation in the parents and other relatives in the English and Irish families, we found that $48(29$ mothers and 19 fathers) out of 360 parents $(13.3 \%), 38$ out of 581 aunts $(6.5 \%), 21$ out of 471 uncles $(4.5 \%)$, and 46 out of 2037 cousins $(2 \cdot 2 \%)$ went to ESN(M) schools (table 5). However, many of these cousins were under school age and this last figure is probably an underestimate.

The recurrence risk in sibs of Asian index children was considerably lower (one out of 118) than in the non-Asian families and we therefore considered this point in more detail, using additional data from a study of ESN(S) schools in Coventry. ${ }^{12}$ The distribution of children in the lower IQ ranges and the recurrence rates in sibs are presented separately for Asian and non-Asian children in table 6.

Finally, we considered the recurrence risks in sibs according to the presence or absence of perinatal problems and other features in the index patient, and these are presented in table 7 . The recurrence in sibs was less, but not significantly so, if the index patient had an IQ below $50(15 \%)$ than above $50(20 \%)$. The recurrence in sibs of index patients with very low birth weights was less than that for the whole series, but again not significantly so. Social class, which was classified for the children attending two of the $\mathrm{ESN}(\mathrm{M})$ schools, was also considered. Among the 22 sibs of children belonging to social classes I, II, and IIIN there was no recurrence of mental retardation, whereas for the other families the recurrence rate in sibs was $28 \%$ (69 out of 243 ).
TABLE 5 Prevalence of mental retardation in relatives of different degree.

\begin{tabular}{lll}
\hline & Reed and Reed $^{7 *}(\%)$ & This study (\%) \\
\hline First degree relatives & 33.4 & $13 \cdot 3+$ \\
Parents & 26.3 & $18 \cdot 8$ \\
Sibs & $16 \cdot 3$ & - \\
$\quad$ Children & 16.8 & $7 \cdot 8$ \\
Second degree relatives & 9.0 & $5 \cdot 0+$ \\
$\quad$ Half sibs & & \\
$\quad$ Uncles, aunts & 3.3 & $2 \cdot 2 \dagger$ \\
Third degree relatives & First cousins &
\end{tabular}

*Mental retardation included those who attended normal schools, but who had severe learning difficulties, or an IQ of less than 70 .

tExcluding immigrant families.

TABLE $6 I Q$ distribution of Asian index patients, compared to non-Asian, and the recurrence of mental retardation in sibs (data from present study and from Bundey et al ${ }^{12}$ ).

\begin{tabular}{|c|c|c|c|c|}
\hline & \multicolumn{2}{|c|}{$\begin{array}{l}\text { Index patients from India, } \\
\text { Pakistan, and Bangladesh }\end{array}$} & \multicolumn{2}{|c|}{ Other index patients } \\
\hline & $\boldsymbol{A}$ & $B$ & $\boldsymbol{A}$ & $B$ \\
\hline $\begin{array}{l}\text { IQ* over } 49 \\
\text { IQ }^{*} 35-49 \\
\text { IQ* under } 35 \\
\text { Recurrence of }\end{array}$ & $\begin{array}{r}30(54 \%) \\
19(34 \%) \\
7(12 \%)\end{array}$ & $\begin{array}{c}27(58 \%) \\
17(36 \%) \\
3(6 \%)\end{array}$ & $\begin{array}{r}176(56 \%) \\
74(24 \%) \\
61(20 \%)\end{array}$ & $\begin{array}{r}174(57 \%) \\
71(23 \%) \\
61(20 \%)\end{array}$ \\
\hline $\begin{array}{l}\text { mental retardation } \\
\text { in sibs }\end{array}$ & $\begin{array}{l}4 / 164 \\
(2 \cdot 4 \%)\end{array}$ & $\begin{array}{l}2 / 129 \\
(1 \cdot 5 \%)\end{array}$ & $\begin{array}{l}132 / 654 \\
(20 \cdot 2 \%)\end{array}$ & $\begin{array}{l}127 / 638 \\
(19 \cdot 9 \%)\end{array}$ \\
\hline
\end{tabular}

$A=$ all index patients in this group.

$B=$ excluding the offspring of consanguineous marriages.

* $\mathrm{IQ}$ was measured using the short version of the British Picture Vocabulary Scale for children at ESN(M) schools, and the Vineland Social Maturity Scale for children at ESN(S) schools.

TABLE 7 Recurrence risks in sibs of index patients according to clinical features of patients.

\begin{tabular}{lcc}
\hline & $N o$ & $\%$ \\
\hline $\begin{array}{l}\text { All index patients, all sibs } \\
9 \text { index patients who had gestations } \\
\text { of } 34 \text { weeks or less }\end{array}$ & $100 / 533$ & 18.8 \\
17 index patients with birth weights & $4 / 17$ & 23.5 \\
less than 10th centile and & & \\
$\begin{array}{l}\text { admitted to neonatal unit } \\
25 \text { index patients with birth weights }\end{array}$ & $12 / 46$ & 24.0 \\
$\begin{array}{l}\text { less than 5th centile } \\
15 \text { index patients with epilepsy }\end{array}$ & $6 / 58$ & $8 \cdot 6$ \\
40 index patients who had IQs & $7 / 29$ & $24 \cdot 1$ \\
$\begin{array}{l}\text { less than 50 } \\
41 \text { index patients with } 4 \text { or more sibs } \\
\text { (each family counted once only) }\end{array}$ & $14 / 96$ & 15.0 \\
\hline
\end{tabular}




\section{Discussion}

The relative contributions of genetic and sociocultural factors to the normal range of intelligence have been discussed by many authors and summarised in two recent reviews. ${ }^{34}$ The methods have been to measure intelligence in pairs of relatives (biological and adoptive) using different tests and making allowance for age. The results of many studies (for example, on 25000 pairs of sibs) are similar and show that the higher the proportion of genes shared by two relatives, the higher the average correlation between their IQs. Probably 60 to $70 \%$ of the total variation of intelligence in a population is the result of genetic factors and less than $10 \%$ the result of environmental factors outside the family. ${ }^{4}$ The genetic component is largely polygenic, that is, composed of many genes individually of little effect. Bouchard and $\mathrm{McGue}^{3}$ considered that there was no evidence of a contribution by $\mathrm{X}$ linked genes, because like sex pairings did not differ from unlike sex pairings. However, an $\mathrm{X}$ linked gene for spatial ability has been postulated. ${ }^{4}$

The distribution of intelligence in the population is Gaussian in shape, and it is reasonable to conclude, as Penrose ${ }^{1}$ did, that mildly retarded children belong to one extreme of this distribution, and that therefore the genetic component of their retardation is also polygenic. However, such a view is incomplete with regard to children attending ESN(M) schools, for while community studies of intellectual retardation ${ }^{1816}$ show an equal sex ratio, there is an excess of males in special schools. This effect could be partially because of emotional immaturity and behaviour problems in males, ${ }^{8}$ but one major reason for the excess of males in special schools (at least in the Isle of Wight) was found by Yule and Rutter ${ }^{17}$ to be the result of a delay in reading (reading retardation or reading backwardness), which is out of proportion to the intellectual retardation and which is commoner in males. This particular problem could well have a genetic basis, and its greater incidence in males suggests the presence of $\mathrm{X}$ linked genes.

The family study described here has looked not at IQ measurements in relatives, but at their need to be educated in special schools. We were unable to obtain information about the families of the 116 children whose parents withheld permission for study. There are several possible explanations for the high refusal rate, but perhaps the most likely is that parents consider their mildly retarded children to have educational rather than health problems, and therefore see little point in medical research. Altogether, 0.8 per 1000 of all school children in Coventry were found in $\operatorname{ESN}(M)$ schools. On the basis that the expected prevalence of mild retardation $\stackrel{\mathbb{P}}{=}$ is 20 per $1000,{ }^{16} 18$ then just under half such children $\overrightarrow{\vec{F}}$ in Coventry are at special schools, similar to the proportion found in other studies. ${ }^{8}{ }^{16}$ The sex ratio of index patients was 1.5 and this was particularly $\frac{\bar{m}}{0}$ accounted for by an excess of males in the IQ range $\frac{\pi}{\widetilde{\alpha}}$ over 70, where there were 43 males and only 18 응 females.

Previous studies on mild mental retardation ${ }^{6-8}{ }^{19} \vec{\circ}$ have provided figures which show a recurrence in sibs ranging from 13 to $23 \%$, in parents from 29 to $\vec{\omega}$ $33 \%$, and in offspring from 17 to $31 \%$. The present study is less easy to interpret because of theo associated factors which lead to the excess of malesiू in special schools, and because the presence of one ${ }_{-}^{\circ}$ child in an ESN(M) school might encourage otherĩ dull children in the family to be similarly placed. In 0 table 5, our results are compared with those of Reed은 and Reed $^{7}$ whose figures are somewhat higher,owing to their inclusion of relatives with severe learning difficulties or a low IQ but who attended․ㅡ․ normal schools. The observed rates of recurrence in $\vec{\bullet}$ sibs in both studies were greater if a previous sibog (other than an index patient) had been affected, or if ${ }^{\circ}$ one parent was affected (table 3 ). The recurrenceso in second and third degree relatives (table 5), while significantly greater than the population incidence, $\bar{\partial}$ were much less than in first degree relatives. These observations are consistent with a polygenic predis- $\varrho$ position of a multifactorial trait. ${ }^{20}$ The greater risk $\vec{O}$ for sibs compared to parents seen in this study might 3 suggest a contribution by single genes, but a similar discrepancy has not been found by other workers. ${ }^{6-80}$

In 1974 Lehrke $^{21}$ persuasively argued that some if not all of the male excess among retarded children ino special schools could be explained by $\mathrm{X}$ linked $\overline{3}$ genes, and he pointed out that evidence for this:suggestion was provided by an excess of affected brothers and sons. He was indeed correct, for since then the fragile $\mathrm{X}$ syndrome has been shown to음 account for $8 \%$ of mild mental retardation. ${ }^{9}$ Has this $D$ syndrome accounted for all the $\mathrm{X}$ linked genes contributing to mild mental retardation, or is there N still evidence for other $\mathrm{X}$ linked genes? The sex ratioof 1.5 among index patients in this study was not 0 reflected by a similar excess of affected male $\tilde{\omega}$ relatives (table 4). In particular, there was noo increased risk for brothers of male index patientso being affected, nor indeed for their sisters or $\mathbb{\mathscr { D }}$ mothers. Moreover, the number of sibships of male $\stackrel{?}{?}$ index patients with males only affected (16) is equal 0 to the number with both males and females affected. There is therefore no evidence in this study for $a_{\Omega}^{\mathbb{D}}$ contribution by $\mathrm{X}$ linked genes (once the fragile $\mathrm{X} \stackrel{\mathbb{Q}}{\mathrm{Q}}$ syndrome has been excluded) which could contribute either to the excess of males with reading disabilities, 
or to any other reason for the excess of males in special schools. Indeed, the slight tendency of relatives of female probands to carry a higher recurrence risk than the relatives of male probands (table 4) suggests that the female probands are more genetically predisposed. The only discrepancy lies in the small number (five) of sibships with females only affected. This surprising observation may tentatively be ascribed to a greater chance of a female being sent to an ESN(M) school if she has a retarded brother rather than if she has a retarded sister.

Morton et $a l^{22}$ proposed that a few autosomal recessive genes of major effect contribute to mild mental retardation, their evidence coming from the level of inbreeding. Such a suggestion remains a possibility in our data, where two out of 186 English/Irish parental couples were consanguineous (compared to a current parental consanguinity rate in this group of $0.4 \%$ ) and where there is a high sib recurrence risk.

There is evidence in the present study that mild mental retardation in Asians in Coventry has a different aetiology from that of English children. It was interesting that in the Asian families there was a normal sex ratio of index children, and there was also a much lower recurrence of mental retardation in sibs. The figures from two studies which are presented in table 6 show a sib recurrence rate of $2.4 \%$ for Asian index children and $20.2 \%$ for nonAsians. The recurrence risk of $2 \cdot 4 \%$ is similar to that for severe idiopathic mental retardation, 2324 which consists of a heterogeneous group of disorders, mainly non-genetic, but containing a few autosomal recessive diseases. The high risk of mild mental retardation shown by English families is lacking in Asian families, and two possible explanations are suggested. Firstly, it is possible that the intelligence level in their sibs is sufficient to avoid special education, implying that the normal distribution of IQ levels in Asian children in Coventry is centred around a mean that is higher than that of indigenous white children. The second explanation is that mildly retarded Asian children mainly go to normal schools either because they are well behaved or because teachers in Coventry are reluctant to label Asian children as ESN(M). This seems unlikely in view of the fact that for many english is their second language, and any difficulties with language would encourage their entry to $\operatorname{ESN}(M)$ schools.

If Asians do indeed have a higher distribution of intelligence levels, we would expect to find a smaller proportion of them in special schools than anticipated from the general school population. This is not so, but the discrepancy could result from the inclusion of Muslim children with consanguineous parents and presumed autosomal recessive disease. Nine of
56 Asian index children (16\%) were the offspring of consanguineous Muslims, whereas only five of 311 non-Asian children $(1.6 \%)$ had consanguineous parents. If such children are excluded, the remaining distribution of IQ levels shown in table 6, columns $B$, suggests that there might be a real difference between the Asian and non-Asian children, but larger numbers are needed to be sure of this. If the distribution of IQ in Asian children in Coventry is truly higher than that of English children, this could be because of selective immigration of more intelligent families or it could reflect a true racial difference.

We were interested to consider whether there were environmental causes which had a significant influence in causing mild mental retardation. Such possible influences had been rigorously searched for in the children of the National Child Development Study. ${ }^{25}$ The possible aetiological factors which could be studied in the present series were social class, prematurity, birth weight, family size, parental age, and associated clinical features. Table 2 shows that there is an excess of social classes IV and V among the fathers of the index patients, and also larger sized families than expected. These are two well established associations with mild mental retardation. There was no obvious excess of young parents in our study, and the number of prematurely born children and of those admitted to the neonatal unit after birth did not appear to differ from the general population. There was, however, an excess of children with low birth weight and of children with epilepsy.

We thought it interesting to consider if these environmental associations had any effect on the recurrence risk in sibs, for if the risk were reduced it would suggest that the children with associated features were less genetically predisposed to mental retardation than those without. The data are presented in table 7. It can be seen that the recurrence risk in sibs is similar, whether or not the index patient was premature, had a low birth weight for gestation, had epilepsy, or came from a large family. (A possible exception was provided by the families of very low birth weight children, but the numbers did not reach statistical significance.) These observations suggest that these relatively minor perinatal factors (for children with overt cerebral palsy were excluded at the outset) do not lower IQ levels sufficiently to bring a child into the mildly retarded range unless that child is also genetically predisposed. From the practical point of view, the presence of an adverse perinatal history should not make a genetic counsellor alter the overall recurrence risk of 1 in 4 to 1 in 5 for affected sibs.

The figures given here can be used for genetic 
counselling and the 1 in 4 to 1 in 5 risk for mental retardation in sibs of mildly affected index patients can be contrasted with a lower risk for mental retardation occurring in the sibs of severely retarded index patients. It should be noted that, since sibs do not normally differ from each other by more than 60 points of IQ, and since the distribution of IQ in children is centred on the mean of the parental IQ ${ }^{26}$ then it is most unusual for very intelligent parents to have a child who is mildly retarded for nonpathological reasons. This is reflected by the very small number of parents in social classes I and II (table 2) and by their low recurrence risk for sibs. With intelligent parents, therefore, pathological causes of the retardation should be rigorously searched for and, in their absence, a low recurrence risk should be given, as for severe mental retardation. In the present series, pathological causes were found for $20 \%$ of mildly retarded children in which the fragile $\mathrm{X}$ syndrome was second in frequency to Down's syndrome (table 1).

We thank the National Fund for Research into Crippling Diseases (Action for the Crippled Child) and the Mental Health Foundation for financial support. We are grateful to Coventry Education Department and to the head teachers of the schools concerned for their help during the study. We thank Dr J Cash for his advice when we planned the studies of Coventry schools and we thank Drs $S$ Green and R M C Huntley for their comments on the manuscript.

\section{References}

1 Penrose LS. The biology of mental defect. London: Sidgwick \& Jackson, 1949.

2 Erlenmeyer-Kimling L, Jarvik LF. Genetics and intelligence: a review. Science 1963;142:1477-9.

3 Bouchard TJ, McGue M. Familial studies of intelligence: a review. Science 1981;212:1055-9.

${ }^{4}$ Scarr S, Carter-Saltzman L. Genetics and intelligence. In: Sternberg RJ, ed. Handbook of human intelligence. Chap 13. Cambridge: Cambridge University Press, 1982;792-896.

5 Roberts JF. The genetics of mental deficiency. Eugenics Rev 1952;44:71-83.

6 Akesson HO. Empiric risk figures in mental deficiency. Acta Genet (Basel) 1962;12:28-32.

7 Reed EW, Reed SC. Mental retardation: a family study. Philadelphia: Saunders, 1965.
${ }^{8}$ Birch HG, Richardson SA, Baird D, Horobin G, Illsley R. Mental subnormality in the community: a clinical and epidemiologic study. Baltimore: Williams \& Wilkins, 1970.

9 Thake A, Todd J, Webb T, Bundey S. Children with the fragile$\mathrm{X}$ chromosome at schools for the mildly mentally retarded. Dev Med Child Neurol 1987;29:711-9.

10 Thomson AM, Billewicz WZ, Hytten FE. The assessment of fetal growth. J Obstet Gynaecol (Br Cwlth) 1968;75:903-16.

11 Brooke OG, Butters F, Wood C, Bailey P, Tukmachi F. Size at birth from 37-41 weeks gestation; ethnic standards for British infants of both sexes. J Hum Nutr 1981;35:415-30.

12 Bundey S, Webb TP. Thake A, Todd J. A community study of severe mental retardation in the West Midlands and the importance of the fragile X chromosome in its aetiology. J Med Genet 1985;22:258-66.

13 Birth Statistics England and Wales. Office of Population Censuses and Surveys. London: HMSO, 1984: table 4·1.

${ }^{14}$ Registrar General's Statistical Review of England and Wales 1972. II Tables, Population. London: HMSO, 1974.

15 Census (1981). Key statistics for urban areas: the Midlands. London: HMSO, 1984.

16 Rutter M, Tizard J. Intellectual and educational retardation: prevalence and cognitive characteristics. In: Rutter M, Tizard J, Whitmore K, eds. Education, health and behaviour. Chap 4. London: Longman, 1970:39-53.

17 Yule W, Rutter M. School placement of children with intellectual or educational retardation. In: Rutter $M$, Tizard J, Whitmore $\mathrm{K}$, eds. Education, health and behaviour. Chap 9. London: Longman, 1970:130-43.

18 Clarke AM, Clarke ADB. Mental subnormality. In: Eysenck HJ ed. Handbook of abnormal psychology. 2nd ed, chap 7. Belfast: Pitman, 1973:212-58.

19 Scally BG. The offspring of mental defectives. In: Woollam DHM, ed. Advances in teratology. Vol 3. London: Logos Press, 1968: $65-84$

${ }^{20}$ Carter CO. Genetics of common disorders. Br Med Bull 1969;25:52-7.

${ }^{21}$ Lehrke RG. $X$ linked mental retardation and verbal disability. Birth Defects 1974;10:No 1.

22 Morton NE, Rao DC, Lang-Brown H, Maclean CJ, Bart RD, Lew R. Colchester revisited: a genetic study of mental defect. J Med Genet 1977;14:1-9.

23 Bundey S, Carter CO. Recurrence risks in severe undiagnosed mental deficiency. J Ment Defic Res 1974;18:115-34.

24 Herbst DS, Baird PA. Sib risks for non-specific mental retardation in British Columbia. Am J Med Genet 1982;13: 197-208.

${ }^{25}$ Mascie-Taylor GCN. Biosocial correlates of IQ. In: Turner CJ, Miles HB, eds. The biology of human intelligence. Chap 7 . Driffield: Nafferton Books, 1984:99-127.

${ }^{26}$ Huntley RMC. The exceptional child in the family. In: Turner CJ, Miles HB, eds. The biology of human intelligence. Chap 10. Driffield: Nafferton Books, 1984:151-62.

Correspondence to Dr S Bundey, Clinical Genetics Unit, Birmingham Maternity Hospital, Birmingham B15 2TG. 